\title{
Ethnography, Historiography, and the Making of History in the Tradition of the Anastenaria
}

\author{
Dimitris Xygalatas
}

In five villages of Northern Greece, the communities of the Anastenaria have a long tradition of fire-walking rituals. The Anastenaria are Orthodox Christians, and their rituals are performed in honour of saints Constantine and Helen. However, the majority of Greek scholars have argued that these rituals originate from the ancient orgiastic cults of Dionysus. This theory was intentionally designed to serve specific political agendas, namely to prove the continuity of Greek civilization from ancient to modern Greece. Despite lacking any evidentiary support whatsoever, it became the dominant view of the Anastenaria for more than a century and has heavily influenced not only the ethnographic representation of this tradition but also the tradition itself. This article explores ethnographic practice in the context of the Anastenaria, its effects on this tradition, and the implications for further anthropological research on the subject.

Keywords: Anastenaria; Fire-Walking; Ethnography; Greece; Bulgaria

Who controls the past controls the future. Who controls the present controls the past. (George Orwell, Nineteen Eighty Four)

\section{Introduction}

In his legendary dystopian novel, Nineteen Eighty Four (1948), George Orwell described how the Party, the totalitarian government of a fictional country called Oceania, effectively managed to control the present, and thereby have power over the

Correspondence to Dr. Dimitris Xygalatas, Aarhus University, Jens Chr. Skous Vej 3, Build. 1451, Off. 422, Aarhus C. 8000, Denmark. Email: xygalatas@mac.com 
future, by manipulating the past. Although I do not wish to carry this analogy too far, there is an important lesson to be drawn from Orwell's narrative regarding the tradition of the Anastenaria: what we write about a particular culture as historians or ethnographers can often have implications for the future of this culture. This article will discuss the ethnographic study of this tradition, the theory of its Dionysian origins and its effects on the tradition itself.

The Anastenaria ${ }^{1}$ are religious communities of Orthodox Christians, known for their devotion to Saints Constantine and Helen and the fire-walking rituals they perform in their honour. These rituals are part of an elaborate annual ritual cycle, which culminates with the festival of the two saints every May. The festival, which lasts for three days, includes various processions around the village, an animal sacrifice, music and ecstatic dancing. The most dramatic moment of the festival is the fire-walking ritual itself, where the participants, carrying the icons of the saints, dance over the glowing coals.

This practice is very old. Since the nineteenth century, Greek ethnographers have almost unanimously argued that the Anastenaria derive from the ancient orgiastic cults of Dionysus, constituting a continuous tradition of almost three millennia. This is something that most people who have heard about the Anastenaria know, and to which many Greek anthropologists attest. However, such a claim is completely unfounded; a more careful study of the sources reveals that the theory of the Dionysian origins of the Anastenaria has been intentionally constructed and later uncritically reproduced, resulting in a false version of history, which has had profound effects on its study, as well as the tradition itself (Danforth 1984; Xygalatas 2007).

\section{The Anastenaria in Eastern Thrace}

The tradition of the Anastenaria was brought to Greece by refugees from the area of Strandja, at the Black Sea coast, which today is split between Turkey and Bulgaria. Until the nineteenth century, this area was inhabited by Bulgarians, Greeks and Turks. The rituals of the Anastenaria were performed in several villages with either Greek, Bulgarian or mixed population. Fire-walking was performed on various important dates of the Orthodox calendar, such as 8 September (the birth of the Virgin Mary), 18 January (Saint Athanasios' day), 21 May (Saint Constantine and Helen's day), and 24 June (Saint John’s day) (Hourmouziadis 1873: \$6). Each village had its favourite Saint, for example Saint Panteleimon or Saint Elias, but the most popular one was Saint Constantine. Each village had a sacred well called ayiasma, from which holy water was drawn, and a chapel, where the sacred icons of the saints were kept. The most prosperous village in the area was Kosti, with a population of 180 families $(\$ 5)$ in the mid nineteenth century and a few thousand people in the beginning of the twentieth century (Danforth 1989: 133). Kosti was home to the most important fire-walking festival, held every May in honour of Saints Constantine and Helen.

The festival lasted for eight days. A sacrificial bull was slaughtered and the meat was then distributed around the village. In the evening, a big fire was lit. After dancing for 
several hours to the melodies of the Thracian lyres, drums and bagpipes, the Anastenaria, led by their leader, the archianastenaris, started walking over the glowing red coals, carrying the icons of the saints. After the performance of fire-walking, they carried their icons to the nearby villages, thus allowing the depicted saints to "visit" their "brother" and "sister" saints (Hourmouziadis 1873: \$18).

The icons were kept in the conaki, a special room in the house of the archianastenaris. They were often called "Grandfathers" (pappoudes), like Saint Constantine, who was also called "Grandfather" among the Anastenaria. Since Kosti was the most important village, its icons were also more respectable, and so was its archianastenaris.

The Anastenaria were considered to have special religious knowledge and their icons were believed to be miracle-working. People often visited them and asked them to interpret their dreams, offer them advice or help them overcome an illness. The Anastenaria used their icons to cure the sick, produce rain, protect the crops and livestock from diseases or prevent some natural disaster. They listened to people's confessions, foretold the future and exposed thieves and other transgressors (Hourmouziadis 1873; Petropoulos 1938-1939: 141).

This, in broad lines, is what we can tell with any certainty about the recent history of the Anastenaria, based on ethnographic and historical evidence as well as on personal reports. On the other hand, we know very little—in fact, close to nothing — regarding the origins or the dating of this tradition. But despite this lack of evidence, the majority of Greek scholars have argued that the Anastenaria originate from the ancient orgiastic cults of Dionysus (Hourmouziadis 1873; Kourtidis 1938-1939; Diamantoglou 1952, 1953; Kakouri 1999). We will see that this claim is not only totally unfounded but calculatedly constructed to serve specific political agendas.

\section{Fallmerayer, Hourmouziadis and the Theory of Dionysian Origins}

The Patriarchate of Constantinople was not favourable towards the Anastenaria, whose customs diverged from the established Church practices. It condemned the performance of their rituals, deeming them pagan rites, primitive relics and acts of ignorance that were not "in line with the practices of the Mother Church" (Hourmouziadis 1873: $\$ 1)$. The clergy opposed the Anastenaria, often using violent means (\$29).

At the end of the nineteenth century, the Patriarch asked a professor of theology, Anastasios Hourmouziadis, to run an investigation and write a report on the Anastenaria. Hourmouziadis never actually saw the Anastenaria, nor did he visit the villages in which they were performed; by his own admission, his reports were based on information that he received from two priests who had served at those villages (\$27). Those priests criticized the Anastenaria for failing to attend church regularly and because they did not give tips to the clergy. Based on their reports, Hourmouziadis described the Anastenaria as mentally ill and completely uneducated (\$23) and accused them of superstition, drunkenness, orgies and sacrifices to Aphrodite $(\$ 16-20,26)$. For those reasons, as he admitted, the clergy had persecuted the Anastenaria "with the axe, the fire and the whip", and the bishops had very often threatened and beaten the Anastenaria and thrown their icons into fire (\$29). 
Despite all that, Hourmouziadis also saw some utility in the study of the Anastenaria, in his attempt to address a debate of national importance for Greece. A few decades earlier, and just after the first Greek state was established, gaining independence from Turkey, Austrian historian Jakob Philipp Fallmerayer had proclaimed that the contemporary inhabitants of Greece had no racial relation to the ancient Greeks (1830; 1835; 1836). According to Fallmerayer, until the sixth century AD, the Greeks had been a "pure" race, without any foreign elements; the decline of Greek civilization started with emperor Justinian and the Byzantine rule. Once Greece was weakened, Slavic tribes invaded it and wiped out its population. The problem for Fallmerayer, who drew his main arguments from linguistics and onomatology, was that modern Greeks continued to speak the Greek language. He dealt with this problem by claiming that the "real" Greek language was the one spoken until the sixth century, with its Dorian and Ionian variants. The Modern Greek language was a "barbaric" form of Greek and was brought back to Greece in the ninth century, when the Byzantines conquered the mainland and wiped out the Slavic element. Finally, Fallmerayer claimed that in the beginning of the nineteenth century, Greece's inhabitants were mostly of Albanian origin.

Fallmerayer's work was deeply ideological, driven by political motives and aspirations. Following the Realpolitik of his time, he was interested in the maintenance of the post-Napoleonic status quo, which he felt was threatened by Slavo-Russian expansionism (Romanos 1984). He considered Russia to be the biggest menace against the Germanic nations and thus wanted a strong Ottoman empire, capable of preventing the Russians from gaining access to the Mediterranean Sea. To this purpose, he made an appeal to the European forces to abandon their Philhellenism and suppress the Greek revolution against the Turks. His main argument was that modern Greeks, having been "corrupted" by Slavic blood, were not worthy of Europe's help and sympathy.

Fallmerayer's ideas caused a ferocious reaction from Greek and Philhellene scholars and triggered a search for the continuity of Greek civilization from ancient to modern Greece (Danforth 1984). The profound effect of his ideas on Greek scholarship of the nineteenth century is aptly captured by the title of a book authored by Giorgos Veloudis, Jakob Philipp Fallmerayer and the Birth of the Greek Historicism (1982). Indeed, Greek historiography emerged largely as a reaction to Fallmerayer's theory, in order to make a case for the continuity of Greek civilization (see Paparrigopoulos 1843). The link between modern and ancient Greeks had already been emphasized by Greek Enlightenment scholars, who nonetheless considered the Byzantine rule as a dark age, a theocratic and obscurantist regime that separated the two periods of Hellenism (Demaras 1994). On the other hand, certain historians (Zambelios 1852; Paparrigopoulos 1853) argued that the Byzantine era was not a period of decadence but one of revival of ancient Greek culture, combined with Christianity. According to this perspective, Byzantium was seen as the link between ancient and modern Greece and the precursor of the modern Greek civilization, which is now described as "GreekChristian" (Zambelios 1852).

Those Greek scholars were heavily influenced by German Romanticism, that opposed the rationalism of the Enlightenment and stressed the priority of emotion over logic, particularities over universalities, and the past over the future. The focus was 
placed on the nation, its origins and its unique attributes, and nationalism became one of the central themes of Romanticism as well as the key concept of German scholarly discourse (Kyriakidou-Nestoros 1978: 17-33). For the German Romanticists, each nation had a special, unchangeable essence, described as the "folk spirit" (volksgeist), which was not subject to external sociopolitical influences. This spirit could be traced in traditional folklore expressions, and especially those found in rural areas, which were seen as pure and uncontaminated from the polluting influences of industrialism. Romantic ethnography was placed in the service of the ethnic State, which was based on the concept of racial consciousness, that was considered not as a cultural but as a biological category. The purpose of German ethnography was to strengthen-or create-national consciousness and self-awareness, as well as to manipulate it according to the needs of the State (Kyriakidou-Nestoros 1997: 32).

This need for national unity and self-awareness was more than urgent in the newly founded Greek state, and Greek scholars saw in the German model an opportunity to show that the modern inhabitants of Greece were the direct descendents of ancient Greeks and beneficiaries of their cultural heritage. The goal was twofold: internally, to establish a national consciousness; and externally, to evoke the sympathy of the European powers, taking advantage of the movement of Philhellenism that was developing in western Europe, whose proponents were dreaming of a revival of ancient Greek civilization. Many of those Europeans had an idealized image of Greece, which was based on its glorious past that was seen as the foundation of Western civilization. However, the population of modern Greece mostly consisted of uneducated peasants, whose life and customs were seen as "barbaric" and "Oriental" by Greek intellectuals, who saw this as a hindrance to their attempts to gain international support for the Greek plans of expansion. To solve this problem, Nikos Politis,

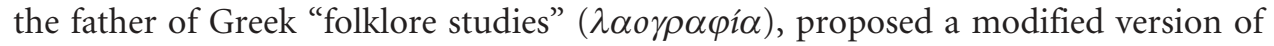
Edward Tylor's theory of "survivals" (Tylor 1871), focusing exclusively on those elements of Greek culture that appeared to have some relationship to antiquity. For Politis, the customs of Greek peasants were not irrational or barbaric but descended from the higher levels of ancient Greek civilization; they were, as he called them, "living monuments of Greek antiquity" (Politis 1914). Thus, he-somewhat clumsily_combined Tylor's comparative method with Romantic historicism. While he searched for parallels of the customs that he studied in other cultures the world over, he denied the possibility that those customs could have spontaneously arisen in contemporary Greece, as they did elsewhere, for Greek peasants, despite being "vulgar and ignorant", were still too civilized to have made up such infantile representations (1894). Those latter were to be found in earlier stages of Greek cultural evolution. In this way, the Greek ethnographic synthesis appropriated rationalist ideas within an overly Romantic setting, just like Greek Enlightenment had promoted reason, science and secularization, while at the same time endorsing a Romantic view of history (Kyriakidou-Nestoros 1997: 32).

It was within this context that Hourmouziadis wrote his text and saw the Anastenaria as an opportunity to support the case for the continuity of Greek civilization. Thus, the explicit purpose of his report was twofold: on the one hand, it was 
polemical, describing and opposing "those rituals that spring from darkness and ignorance" and "diverge from the customs of the Mother Church". On the other, it was also apologetic, aiming "to disprove those Western European scholars who have falsely contradicted our descent from the ancient Greeks” (\$1). Hourmouziadis claimed that the Anastenaria derived from the ancient orgiastic rites of Dionysus. Although he stressed their importance for the demonstration of the continuity of Greek culture, he opposed their practice, deeming them heathen and primitive acts. To resolve the conflict, he concluded that despite being descended from idolatrous practices, the Anastenaria had been Christianized and associated with the worship of Saints Constantine and Helen. He maintained, however, that the Anastenaria should be educated by the Church in order to become enlightened and cease the performance of those rituals.

In his description of the ritual, Hourmouziadis is willing to attribute a Dionysian origin to anything one can think of. The sacrifice of a bull is connected to Dionysus's descent from a bull. The oreibasia (frenzied barefoot mountain-climbing) practised by the ecstatic worshipers of Dionysus, is compared to the formal visit paid by the Anastenaria to the neighbouring villages, that just happened to lie on the mountainside. The omofagia (devouring of the raw flesh of live animals), practised by the ancient Bacchae (Euripides, Bacchae 138), is equated to the distribution of raw meat among the Anastenaria after the sacrifice $(\$ 30)$. What Hourmouziadis does not mention, however, is that the Anastenaria of course always cook this meat before eating it (in this respect, it is no different from purchasing raw meat from the butcher). Hourmouziadis concludes triumphantly that he has proven "with a great mass of evidence" that "we are the worthy children of our immortal forefathers" $(\$ 43) .^{2}$

Hourmouziadis's work established a theory on the origin of the Anastenaria that was based on inaccurate facts and far-fetched assumptions, but had profound effects on the study as well as the performance of the Anastenaria. On the one hand, the theory of the orgiastic origin of the ritual provided the Greek Church with a casus belli and triggered a persecution that is still ongoing. On the other hand, this theory has been widely influential for Greek ethnology and served specific nationalist agendas.

\section{The Anastenaria in Greece}

Eastern Thrace was part of the Ottoman Empire until 1885. However, during the last quarter of the nineteenth century, and as unrest against Turkish occupation spread throughout all Balkan countries, the area became particularly unstable, with constant conflicts and territorial repartitions. Eventually, the conflicts escalated into the Balkan Wars. The area fell under Bulgarian control, and finally officially became part of Bulgaria. A few years later, the Treaty of Lausanne (1923) imposed the exchange of Greek, Bulgarian and Turkish populations, and the Greeks of Strandja were forced to move to the Greek part of Macedonia. They took their icons with them and they continued to perform their rituals, and within a few years the majority of them had settled in the five villages of Northern Greece where their festivals are celebrated today. A few Bulgarians still perform the Anastenaria in their original location in the Strandja 
mountains; however, their number has diminished greatly and the tradition seems to be dying out.

When the Anastenaria arrived at Greece, they celebrated their rituals in secret, for fear of an adverse reaction from the Greek Church and the local population. Firewalking was performed indoors, in a special room called the conaki. The fire was lit in the hearth and the coals were spread on the floor, which had been covered with soil and manure. The Anastenaria danced over the burning coals until they were put out.

\footnotetext{
Nobody knew about the Anastenaria ... not even our neighbours. On the day of Saint Constantine, people would hear the lyre and the drums playing and ask my father: "What is all this fuss about?" "We're celebrating my brother Costas' name-day", he would answer. "But your brother is dead!" they would say. "So what?" my father would reply. "Shouldn't one celebrate for the dead? Shouldn't one honour them?" (Personal interview with an Anastenaris)
}

About twenty years later, the Anastenaria were performed in public again. In 1928, an Athenian doctor and president of the Greek Society of Psychic Research, Angelos Tanagras, who had an ethnographic interest in the ritual, went to Bulgaria searching for the Anastenaria and found that they had moved to Northern Greece. Several years later, he finally managed to trace the Anastenaria of Mavrolefki, and in the 1940s he persuaded them to perform the ceremony in public again (see Christodoulou 1978: 148).

\section{Ethnography on the Anastenaria}

Meanwhile, Greece was going through a period of prolonged turbulence and political uncertainty. Even after the Treaty of Lausanne (1923), the threat of further territory loss was still in the air and yet the ideas of a "Greater Greece" had not been forgotten. For the following three decades, governments would change every few months or even days and the political system would constantly swing between republic, monarchy and militarist coups. Amid this search for national identity and sovereignty, Greek ethnography and historiography were mainly dedicated to defending Greek cultural identity and the continuity of Greek civilization, a trend that was even more apparent in newly added northern Greece. In Thrace, two ethnological journals were founded, Thracica $\left(\Theta \rho \alpha \kappa \imath \kappa \alpha^{\prime}\right)$, in 1928, and shortly after, in 1934, the Archives of the Thracian Ethno-

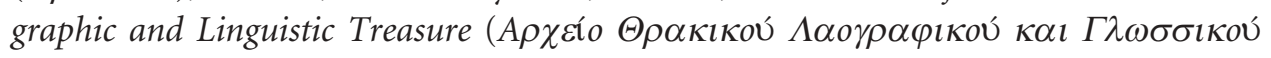
$\Theta \eta \sigma \alpha \cup \rho o u ́)$. They were both directed by Polydoros Papahristodoulou, a schoolteacher. There were no ethnologists among their founders and their boards consisted of doctors, politicians, stockbrokers, bankers, pharmacists and other well-respected Thracians (Archives of the Thracian Ethnographic and Linguistic Treasure 1934-35, d). The two journals had the same goals (Thracica 1928, c): "to proclaim for the ten thousandth time that Thrace has always been the cradle of Hellenism ... and call the Thracian brothers to unite, get organized, and prepare for glorious patriotic action".

Soon, the first articles on the Anastenaria of Kosti appeared in the Archives of the Thracian Ethnographic and Linguistic Treasure. Without ever having witnessed the rituals of the Anastenaria, the authors of these articles relied exclusively on the accounts of 
Hourmouziadis and followed his example, referring to their festivals as orgiastic Dionysian rites (Petropoulos 1938-1939; Deligiannis 1938-1939; Kourtidis 19381939). Even when it became known that the Anastenaria were now performing their rituals in Greece, these ethnographers did not bother to visit them but continued to write about them based exclusively on Hourmouziadis's report on the Anastenaria of the Strandja area from the nineteenth century.

Papahristodoulou himself started writing on the Anastenaria (1950) when, as he says, he realized that

It would be a pity not to take advantage of [the Anastenaria] —at least from a nationalist viewpoint-since their existence confirms the presence of Hellenism in Thrace for the last three thousand years. The Bulgarians, to their credit, take advantage of such important phenomena. (1950: 309)

Before long, other authors adopted the idea of the Dionysian origin of the Anastenaria (e.g. Diamantoglou 1952; 1953); but the best-known proponent of this theory, who took it to its extreme, is theatrologist Katerina Kakouri. For her, the entire history of Christianity seems to be based on Dionysian elements. In her work she uses almost exclusively Christian sources, and the search for "historical facts" (sic) leads to the Old Testament, which provides evidence for the Christianization of the ancient Greek ecstatic cults (Kakouri 1999: 60). Any reference to ecstatic rituals is considered as a clear case of Dionysian survival. Thus, the Anastenaria are remnants of the ancient worship of Dionysus, and the fire-walkers are referred to as "Bacchants", or "BacchantChristians". For the purpose of demonstrating the connection between the Anastenaria and Dionysian rites, Kakouri stresses minor, often arbitrary similarities, ignoring significant differences. She relies on Hourmouziadis's text, which is given authoritative status in her work. She even claims that Hourmouziadis went to Thrace and studied the Anastenaria (Kakouri 1999: 2-3,11), while he himself states plainly that he had never been to that area (Hourmouziadis 1873: \$27). An example of the degree of uncritical reproduction of Hourmouziadis's arguments by Kakouri is her mention of the oreibasia (mountain-climbing) practised by the ecstatic worshipers of Dionysus, as another parallel between the two cults. Having read Kakouri's work, when I arrived for the first time at the village of Ayia Eleni, where I did fieldwork for my doctoral dissertation and where Kakouri also did her own research, I expected to see a mountain village. However, Ayia Eleni is situated in a valley, at a distance of $20 \mathrm{~km}$ from the nearest mountain. Naturally, when I asked the Anastenaria if they climb the mountain during the festival, they were puzzled and amused at my question.

Kakouri's claim for the undisturbed historical continuity of Dionysian elements from prehistory until modernity (Kakouri 1999: $\mathrm{x}$ ) and her attempts to bridge a 2000year gap between the Bacchic cult and the modern firewalkers are unconvincing. Attempting to find the missing links, she mentions various medieval "heretic" groups. The similarities between those groups and the Anastenaria are "their enthusiastic and popular character, the formation of independent religious groups, their fundamental belief in the existence of Good and Evil ... and the sanctity of fire and water" (Kakouri 1999: 68). Her reference to medieval texts of the twelfth and thirteenth centuries mentioning groups of possessed people called "Sthenaria", or "Psycharia" (80-81) does 
not seem to have any relevance either, as these texts include no reference to fire-walking or even fire. Besides, there is no evidence that the worshippers of Dionysus performed any kind of fire-walking in the first place, something that Kakouri acknowledges (7273). To support her case, she refers to Strabo's description (72) of a case of fire-walking in Cappadocia. ${ }^{3}$ Moreover, on the next page she quotes another passage from Strabo, which refers to a different case of firewalking, this time in Italy. ${ }^{4}$ She concludes: "It would seem impossible that the ritual of fire-walking was transmitted to the Thracian Dionysians (sic) by the Romans, who had only temporarily conquered them. It is more likely that fire-walking spread from the temple of Castabala to Thrace". Thus, she goes on to speculate that Christian heretics who left that area brought the custom of firewalking to Thrace after the eighth century (73), something that contradicts rather than confirms her main argument, which is that of the continuity of the custom in Thrace.

The work of Maria Michael-Dede, who wrote various articles based on her fieldwork in Langadas during the 1970s (Michael-Dede 1972-1973; 1978; 1983; 1988-1990), is also driven by similar nationalistic ideas. Although she criticizes the idea of the Dionysian origin of the Anastenaria as unsupported, she follows the same path herself, claiming the ancient origin of the ritual. She cites passages from Homer and Xenophon that praise the heroic nature of the Greeks and the bravery of the ancient Thracian warriors (Michael-Dede 1972-1973: 30-31). This ideal of "the hero-warrior ... friend of the arts", was later transubstantiated into Saint Constantine, the "Saint-Warrior" (32) and is today represented by the Greek fire-walkers. She speaks of the "truth of the actions of the Anastenaria" (23-24), the "purest expression of the Greek soul, which blends the Cross with the sword" (27). Furthermore, Michael-Dede claims that one cannot study the Anastenaria without being familiar with the values expressed in the slogan "fatherland, religion, family" (26), the nationalist motto of the militarist dictatorship that was in power in Greece at the time. Therefore, the privilege of studying and interpreting Greek culture belongs exclusively to Greeks and more specifically those who share the nationalist ideology of the junta.

The most characteristic example of the biases that govern Greek ethnography on the Anastenaria is that of the well-known ethnographer Georgios Megas, which clearly demonstrates an opportunistic and ideological treatment of the subject. Megas began writing about Greek "Dionysian practices" in Eastern Thrace before the performance of the Anastenaria in Greek Macedonia (Megas 1911; 1942-1943). Later, when the festival was publicly held in Greece, he described this tradition, following the consensus, as a Dionysian survival (Megas 1960). What is most interesting is that Megas speaks of the Anastenaria exclusively by describing its performance in Kosti, based on textual accounts. Megas did not witness the festival, even after it had been publicly held for many years, and his lack of knowledge of his contemporary Anastenaria is striking. One of the pictures included in his article shows the archianastenaris of Ayia Eleni firewalking, holding the icon of the two saints, but the caption under the picture says: "The archianastenaris holding the holy Gospel, dancing on burning coals" (Table 15). Ignoring the contemporary performance of the ritual, Megas goes on to make a case for its Dionysian origin, uncritically reproducing Hourmouziadis's arguments. He dedicates much of his article refuting the views of those Bulgarians and Greeks who doubt the 
Dionysian origin of this tradition, thus questioning the Greek racial origin of the Anastenaria (516). The lack of evidence to support this claim, which he acknowledges, does not deter him, as "there is only a small distance between ecstatic dancing and firewalking". It is therefore possible that "in times of intense religious frenzy, completely spontaneously... fire-walking appeared, as another evidence of divine synergy, as clear proof of the mystical union between man and God" (524).

Surprisingly, a few years later, Megas completely reverses his position (Megas 1974). His purpose this time is to defend the Anastenaria from the Church's persecution, which he discusses at the beginning of his article. Alarmed by this fact, he sets out to "examine scientifically whether [this custom] is indeed pagan and derives from the orgiastic cults of Dionysus" (4). One by one, the same arguments by Hourmouziadis that were praised in his previous paper are now debunked, and the author concludes that the only similarity between the ancient cult of Dionysus and the Anastenaria is the participants' ecstatic enthusiasm, but in any case the differences are great (Megas 1974: 7). This time, the significant similarity of the Anastenaria is that to medieval Christian mystic movements, such as Hesychasm (11-13). Therefore, the Anastenaria must have a Christian origin. Megas mentions that he visited the Anastenaria "to get a first-hand knowledge of things". However, his single visit, which took place twelve years earlier, only lasted for a few hours, "as it was getting late and we had to go back" (1962: 557). Just as the previous one, this article is exclusively based on reports on the performance of the festival in Kosti, and it seems that the only purpose of mentioning this visit is to add plausibility to his claims. The work of Megas constitutes a typical case of armchair anthropology and shows that the theory of the Dionysian origin of the Anastenaria is not based on any sort of evidence, but on political and ideological agendas.

This theory remained largely unquestioned until Loring M. Danforth's insightful work. Danforth, who conducted fieldwork in Ayia Eleni, offered a critique of the discourse on Greek rural culture and its ideological context (Danforth 1984). He pointed out that this discourse is essentially based on a notion of cultural evolutionism, arguing for the development of Modern Greek culture as the continuation of ancient Greek civilization. However, this same discourse, while considering classical Greece as glorious and superior to other cultures, largely looks down upon Modern Greek practices such as the Anastenaria. Therefore, survivals such as the Anastenaria "constitute important proof of the continuity of the negatively valued present with a positively valued past" (1984: 56).

Danforth suggests that the question of continuity of Greek culture should be understood as an ideological issue involving two groups of people. On the one hand, there is an intellectual elite interested in the question of continuity. On the other hand there are the people of rural Greece, who are seen as superstitious and uneducated, representatives of a primitive and static culture. The members of the first group are the ones who have an interest in presenting themselves as direct descendents of the ancient Greeks, who are idealized and represented as glorious and superior to any other ancient civilization. Thus, they promote a narcissist, essentialist version of Greek history, which reinterprets and censors the past according to what is appropriate in the present. 
Despite Danforth's critique, the theory of Dionysian origins of the Anastenaria is still mainstream in Greek ethnological discourse. During the course of my fieldwork, I discussed this issue with my informants and with many visitors and outsiders to the Anastenaria. Interestingly, there were two different patterns in their answers. As often happens when anthropologists inquire about the origins of an old tradition, the usual answer among my informants was "We don't know how old it is. We've always done it, like our parents, and our grandparents, and their own grandparents have. But no one knew how old it is for as long as anyone can remember." In fact, all the local Anastenaria and those from Eastern Thrace invariably supported this view. Some of them speculated that it probably originated in Christian times and mentioned the various aetiological myths that link it to Saint Constantine.

On the other hand, many of the outsider observers of the ritual mentioned the theory of Dionysian origins. This theory was a very popular subject of discussion among visitors during the festival, and one could often hear journalists, students of anthropology or amateur ethnographers attest to its validity, referring to the work of Megas or Kakouri and pointing to this or that "orgiastic" aspect of the ritual. Similarly, this theory was mentioned to me by some of the younger firewalkers who were not of Thracian descent but had been drawn into the Anastenaria and had read some of these ethnographies.

\section{The Opposition of the Greek Church to the Anastenaria}

Ever since this theory was formulated, it resulted in tensions and persecution from the Orthodox Church, and it was for this reason that when the Anastenaria migrated to Greece, they did not wish anyone to know about their rituals. When they did decide to perform firewalking in public, another cycle of persecution begun. In 1947, the Bishop of Serres wrote to the Holy Synod of the Greek Church, asking what his position should be towards the Anastenaria of Ayia Eleni. The Synod replied that "this pagan custom, originating from the orgiastic feasts of Dionysus, should be abolished, with the use of any spiritual means that the Church has at Her disposition" (Holy Synod 1531/778-26/ 6/1947). A similar encyclical was distributed to various churches in 1952 by the Bishop of Thessaloniki, while the Faculty of Theology of the Aristotle University of Thessaloniki added support by publishing a letter condemning the practice of the Anastenaria.

This initiated a public debate between the clergy and theologians on the one hand, and various ethnologists on the other. Both sides used theological arguments. One group, based on the ideas of Anastasios Hourmouziadis and his followers, condemned the Anastenaria as idolatrous, while others considered them as Satanic or antiChristian (see Christodoulou 1978: 143-149). They argued that firewalking is presented as a miracle. They defined miracles as the suspension of nature's laws and pointed out that they can occur only by divine authority (Evangelou 1994: 53-55). Since the Church, which they considered to be the exclusive interpreter of divine will, was opposed to fire-walking, then it had to be the work of the Devil. Church officials were also concerned about the financial aspects of the issue. They insisted that only the Church had the right to make a profit from religious relics. They claimed that the 
monopoly of the Church was legally established in a Greek public law enacted in 1940, which stated that "any private icon producing income must be confiscated and taken to the nearest church" (Ephemeris ton Nomon 1940: 516). Many ethnologists, on the other hand, claimed that the Anastenaria now constituted a Christianized ritual performed by pious Christians, one of the many pagan elements that the Christian Church had incorporated into its worship (Loukatos 1981). Others pointed out the importance of the Anastenaria as evidence for the continuity of Greek civilization.

Despite the protests, the Bishop of Serres confiscated the icons of the Anastenaria in Ayia Eleni in 1954, thus removing their source of inspiration and power. A villager of Ayia Eleni narrates the following anecdote:

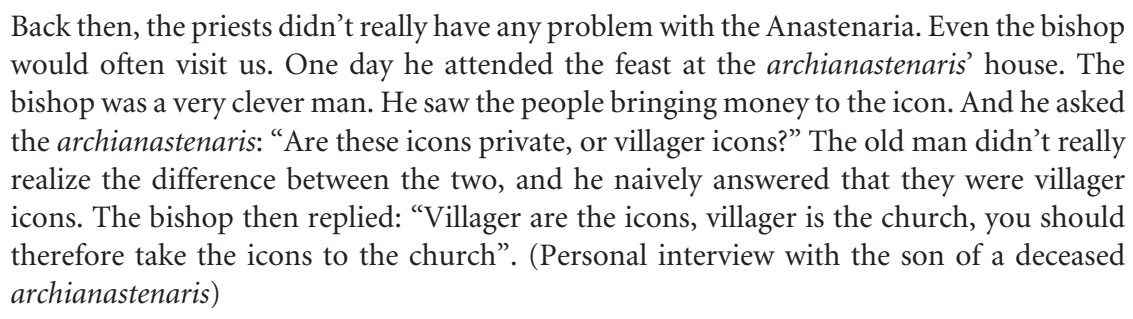
would often visit us. One day he attended the feast at the archianastenaris' house. The bishop was a very clever man. He saw the people bringing money to the icon. And he asked the archianastenaris: “Are these icons private, or villager icons?" The old man didn't really realize the difference between the two, and he naively answered that they were villager icons. The bishop then replied: "Villager are the icons, villager is the church, you should therefore take the icons to the church". (Personal interview with the son of a deceased archianastenaris)

Finally, the firewalkers reached an agreement with the bishop, who allowed the Anastenaria to take place as long as the icons were given to them only on the day of Saints Constantine and Helen for the festival; for the rest of the year, they would have to remain in the local church. Furthermore, all the money collected during the ritual would have to be given to the church. However, the bishop broke this agreement in May 1970 and informed the Anastenaria one week before the festival that they would not be allowed to have the icons. The Anastenaria agreed to perform the festival without the icons as long as they at least remained in the village church. However, on the day of the $21^{\text {st }}$, the icons disappeared "mysteriously". An old woman from the village remembers that day:

\begin{abstract}
The icons had been taken away a lot earlier, but nobody realized it. The church was being refurbished, and the priest moved all the valuables and the icons into the sanctuary, where he would keep them locked until the work was finished. When the church was done, he called us, the young girls, to clean up. I didn't go, but my younger sister did. When they were done cleaning, she told the priest, "Father Alexes, bring us the icons now, and we will hang them up." Father Alexes just smiled awkwardly. When my sister came home she said, "Dad, they have taken the icons! We asked for them and he wouldn't bring them out."
\end{abstract}

The Bishop denied any involvement. After that, the festival did not take place that year. The firewalkers instituted legal proceedings, and the dispute was finally settled in court. In May 1971, the case was examined at the Lower Court of Serres. The Church argued that the icons were not originally private; they belonged to the church of Kosti in Bulgaria and were only lent to the fire-walkers for the performance of the ritual. Therefore, they should now be considered the property of the Greek Church. To support his argument, the Church's attorney cited the dimensions of the icons $(30 \times 40 \mathrm{~cm})$ and claimed that they were too big to be private icons. Both witnesses on the side of the Church were priests, who testified that they had never heard that the icons belonged to 
the fire-walkers. The archianastenaris, on the other hand, argued that the icons were private. One of them had recently been made by an iconographer for him, and the other one belonged to another man's family and had been passed on from one generation to the next. It had been brought to Ayia Eleni by his grandfather when he fled from Kosti, and he inherited it after the death of his own father. Two witnesses, one of whom was a member of the board of trustees of the local church, confirmed his testimony. The decisive evidence was a record of the church committee, dating back to 1950, where the church's property was listed. The two icons were listed under the names of their owners, and the book was signed and sealed by the Bishop himself. Finally, the Court ruled that the icons were the private property of the two families; they were returned to them, and the Church was ordered to pay the court expenses (Christodoulou 1978: 149-152).

Similar opposition has been demonstrated in other communities of fire-walkers. In 1954, local priests and teachers in Langadas protested against the practice of the Anastenaria. As a result, the fire-walkers decided to hold the festival indoors that year, without music and processions. The local bishop refused the church's services to the fire-walkers and their children. The Anastenaria were further refused Holy Communion and were not allowed to get married, become best men or have their children baptized, unless they signed an affidavit that they would never fire-walk in the future. In 1973, the prosecutor of the criminal court of Thessaloniki ordered the police to conduct an investigation into the Anastenaria, after the Bishop's request (Megas 1974: 3). During the three days that the festival lasted, the bells of the cathedral were tolling mournfully. Furthermore, the Bishop claimed that the Anastenaria had been excommunicated by the Holy Synod. In 1977, one of the Anastenaria was refused a wedding permit from the Bishop, because he did not sign an affidavit. The man wrote a letter to the Ecumenical Patriarchate of Constantinople complaining about the Bishop's behaviour. The Patriarchate then informed the Holy Synod of the Greek Church, which sent a letter to the Bishop, ordering him to issue the wedding permit, "as the fire-walkers have never been excommunicated or detached from the Church" (Holy Synod 5144/77/1849 NK).

In Mavrolefki, the Bishop confiscated the icon of the Anastenaria and placed it in a chapel. A few years later, the chapel caught fire and the icon was damaged. Then the Bishop returned it to the Anastenaria, who had it restored. The job had to be done by a specialist, and the cost was very high. All the communities of the Anastenaria helped to raise the money. When the icon was restored in 1969, the bishop had the police confiscate it again, and thus the performance of the ritual ceased in Mavrolefki. Those who wanted to fire-walk went to another community that held the festival. In 1976, the Anastenaria started legal procedures against the Bishop. They asked for the help of the other communities to raise the money for the attorney's fee and finally managed to recover the icon. The Bishop threatened to excommunicate the Anastenaria and even anyone who would light a fire and jump over it (Christodoulou 1978: 159). On the days of the festival, he ordered the village church and the chapel of Constantine and Helen to be shut down (Megas 1974: 3).

Nowadays, the Orthodox Church still opposes the tradition of the Anastenaria, though it no longer has any real power over it. Bishops often speak and write against 
the performance of their rituals, and other clergymen make television appearances condemning them every May. Priests are usually warned by their bishops not to attend the festival. In Ayia Eleni, the village priest discretely takes a holiday and leaves the village every May for the duration of the festival.

\section{Don't Trust the Ethnographer}

Understandably, this hostility led the Anastenaria to become cautious of ethnographers, journalists, authors, and all sorts of researchers probing for information on their tradition. This attitude ranged from simple wariness and unwillingness to openly discuss the subject in most communities to outward hostility in the village of Kerkini, where the locals forbade visitors to take photos or video recordings of the festival.

When I arrived at Ayia Eleni to begin my fieldwork, I experienced this circumspection at first hand. I was warned outright that people would not welcome my questions about their religious practices. Sure enough, my first attempts confirmed this prediction. The locals were very friendly and hospitable; they would invite me into their houses, offer me some coffee and a snack, and discuss for hours. Nevertheless, bringing up the subject of fire-walking was a sure conversation stopper; whenever I asked them about their rituals, they would become laconic and evasive, refusing to talk about the subject or claiming to have no knowledge of it. "We don't know about those things", the young would say. "You'd better ask the elders". And then the elders would respond: "What do I know? Nobody knows the will of the Saints."

I spent several weeks desperately trying to find someone who would be willing to answer my questions. I was hoping that as the festival approached, it would be easier to discuss the subject with the Anastenaria. I was wrong. Indeed, as we moved towards the festival, people would become even more cryptic or avoid the subject altogether. When the festival started, everybody looked very focused and busy, and it was now impossible to establish any kind of contact with them. I often felt as if I were transparent, as if people looked right past me, and their eyes never crossed with mine.

During the remaining days of the festival, not much changed in the attitude of the Anastenaria, but when the festival was over, people were more relaxed and easy to chat with. Within the next few months, they would gradually open up and discuss with me about their rituals for hours. As they explained to me, they did not like those visitors who only showed up before the festival, took some pictures, asked a few questions and then disappeared. My frequent presence was for them an indication of my genuine interest in the ritual and my willingness to get the facts straight.

Of course, almost all field anthropologists have, in the course of their fieldwork, experienced similar initial reticence followed by a gradual increase in people's willingness to collaborate (Hammersley and Atkinson 2007: Ch. 4). People have no reason to spend their time happily answering weird-and very often privatequestions coming from a stranger who often claims to be an authority on their own beliefs and behaviours. At the very least, they expect to know the person on a more personal basis prior to dispensing personal information freely. I myself, for example, 
have encountered this situation while conducting subsequent fieldwork in Spain, studying the fire-walking rituals of San Pedro Manrique. However, it was evident that the Anastenaria were extra cautious when it came to their rituals. After a short initial period, people would freely talk to me about particularly sensitive subjects, such as their financial situation, health problems, politics, and interpersonal relations. It was only their rituals that were almost taboo, and the reason for this-often offered explicitly—was their discontent with what people had written about them in the past.

\section{Conclusion}

The study of the Anastenaria provides an apt example of the way irresponsible ethnographic practice can cause problems not only to the subjects of the study but also to the study itself. It is easy to see how this situation becomes self-reinforcing. As we have seen, the inaccurate descriptions and biased interpretations that have been published by various ethnographers for their own purposes and agendas are, to a large degree, responsible for the ongoing tension between the Anastenaria and the Greek Orthodox Church. This had a direct effect on the tradition itself, resulting in a persecution that has lasted for over a century, which in turn had an effect on the practitioners' view of and attitude towards ethnographers, thus influencing the study of the tradition itself.

Furthermore, it created an unsubstantiated view of the history and the nature of the Anastenaria, which, due to its appeal to the popular press, has come to be endorsed by the majority of the Greek public, and even by some of the Anastenaria, despite the availability of more serious ethnographic works on the subject. Lately, a group of $\mathrm{New}$ Age pagans in Athens were fascinated by the story of the Dionysian origins and began to perform fire-walking rituals, using the same music and symbols as the Anastenaria but replacing the saints with ancient Greek gods. We can easily imagine how this could lead to a resurgence of the Church's attacks on the Anastenaria.

Obviously, the impact of ethnographers on the culture they are studying is to some extend unavoidable. However, in this particular case much could have been avoided. The past of the Anastenaria was intentionally constructed with the aim of serving specific political purposes. Greek ethnography has-more or less unanimouslyuncritically adopted and reproduced this theory, which has had wide implications for the study as well as the performance of the Anastenaria. Thus, in altering this tradition's past, this biased scholarship had an impact on its future, and not for the better. Fortunately, Greek anthropology has come a long way since the days of Kakouri and Megas, and it is my hope that errors of this magnitude will not be repeated.

\section{Acknowledgements}

I would like to thank the Program in Hellenic Studies at Princeton University for offering me the Ted and Elaine Athanassiades Postdoctoral Research Fellowship, during which this article was written. 
Notes

[1] The word Anastenaria is a neuter plural noun (singular: Anastenari) can refer both to the tradition as well as to the individual members of the community.

[2] The Turks followed a policy of religious tolerance within their Empire. During the Ottoman rule, the Patriarchate of Constantinople was the recipient of many privileges and a full tax exempt by the Turks. Furthermore, the Patriarch was treated as the unofficial head of all Christians, and priests became the leaders of local communities and had the right to oversee civil disputes and to supervise education (Stewart 1998). In exchange, the Patriarchate abolished any claims for freedom or independence and called all Orthodox Christians to adopt an attitude of voluntary submission to the Turks (Just 1988). For this reason, when the revolution against the Turkish rule started, the Patriarchate excommunicated the rebels and called all Christians to turn them in to the Turks (Filemon 1859: 112, 309-321; Kordatos 1924; Roudometof 1998; 2001).

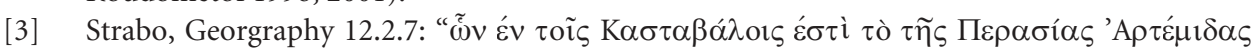

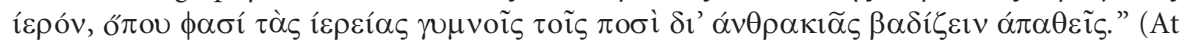
Castabala is a Temple of Diana Perasia, where, it is said, the priestesses walk with naked feet unhurt upon burning coals).

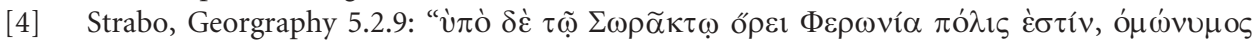

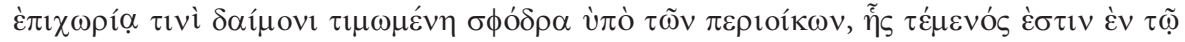

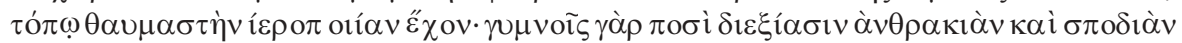

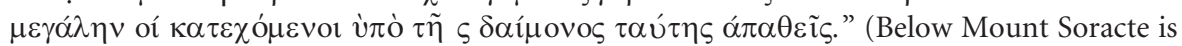
the city of Feronia, having the same name as a certain goddess worshipped passionately by the locals, whose temple lies there, in which a remarkable ceremony is performed; for those possessed by the divinity pass over a large bed of burning coal and ashes barefoot, unhurt).

\section{References}

Christodoulou, S. P. (1978), Continuity and Change Among the Anastenaria; A Firewalking Cult in Northern Greece, Ph.D. dissertation, State University of New York at Stony Brook, University Microfilms, Ann Arbor, MI.

Danforth, L. M. (1984), "The ideological context of the search for continuities in Greek culture", Journal of Modern Greek Studies, (May), pp. 53-85.

Danforth, L. M. (1989), Fire-walking and Religious Healing. The Anastenaria of Greece and the American Fire-walking Movement, Princeton University Press, Princeton, NJ.

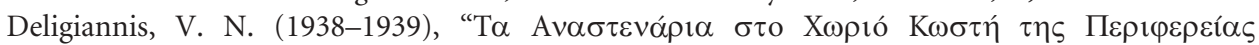

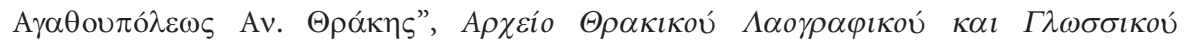

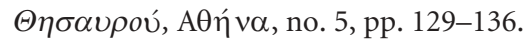

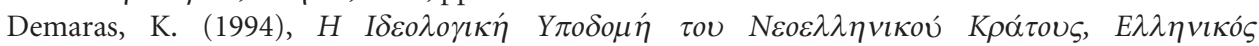

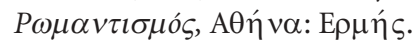

Diamantoglou, M. J. (1952), "Pyrovassie et Incombustibilité”, Revue Métaphysique, no. 18, pp. 82-88.

Diamantoglou, M. J. (1953), "La pyrobatie en Grèce”, Revue Métaphysique, no. 23, pp. 9-19.

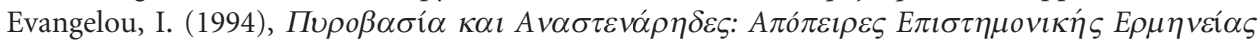

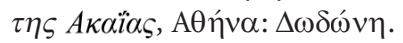

Fallmerayer, J. P. (1830), Geschichte der Halbinsel Morea während des Mittelalters. Teil 1: Untergang der peloponnesischen Hellenen und Wiederbevölkerung des leeren Bodens durch slavische Volksstämme, Cotta'sche Verlagsbuchhandlung, Stuttgart.

Fallmerayer, J. P. (1835), Welchen Einfluss hatte die Besetzung Griechenlands durch die Slawen auf das Schicksal der Stadt Athen und der Landschaft Attika? Oder nähere Begründung der im ersten Bande der Geschichte der Halbinsel Morea während des Mittelalters aufgestellten Lehre über die Enstehung der heutigen Griechen, Cotta'sche Verlagsbuchhandlung, Stuttgart. 
Fallmerayer, J. P. (1836), Geschichte der Halbinsel Morea während des Mittelalters. Teil 2: Morea, durch innere Kriege zwischen Franken und Byzantinern verwüstet und von albanischen Colonisten überschwemmt, wird endlich von den Türken erobert. Von 1250-1500 nach Christus, Cotta'sche Verlagsbuchhandlung, Tübingen.

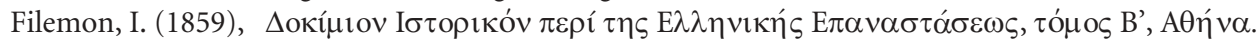
Hammersley, M. and P. Atkinson (2007), Ethnography: Principles in Practice, Routledge, London and New York.

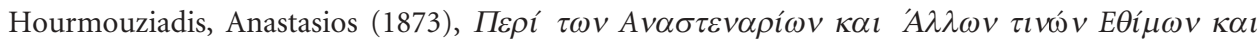

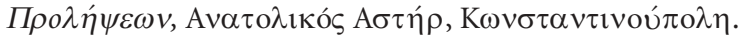

Just, Roger (1988), "Anti-Clericalism and National Identity: Attitudes Towards the Orthodox Church in Greece", in Vernacular Christianity, W. James and D. Johnson (eds), JASO, Oxford.

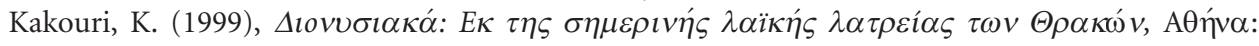
$\mathrm{I} \delta \varepsilon \mathrm{\varepsilon} \theta \dot{\varepsilon} \alpha \tau \rho \mathrm{\rho}$.

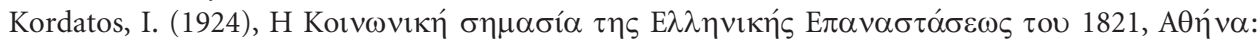
B $\alpha \sigma \imath \lambda \varepsilon i ́ o v$.

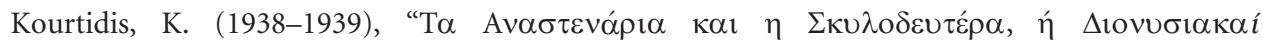

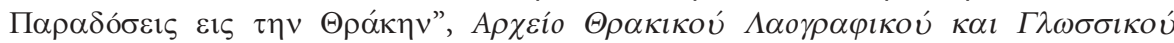

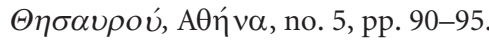

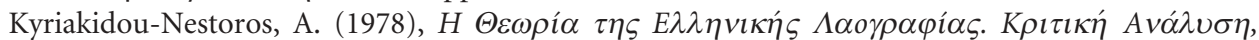

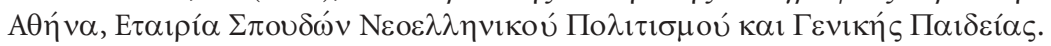

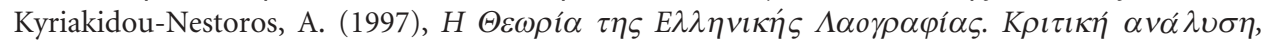

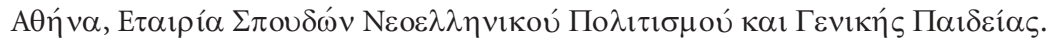

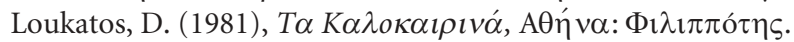

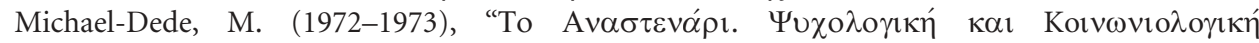

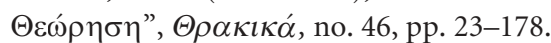

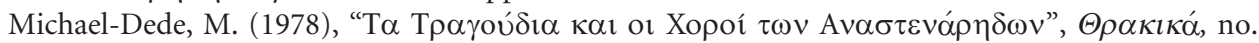
48 , pp. $75-129$.

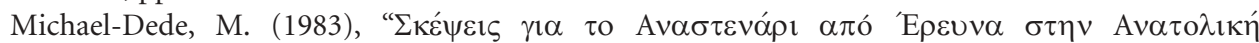
P

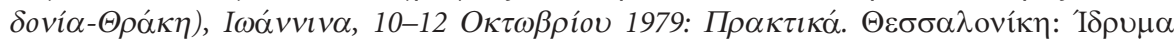

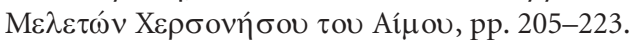

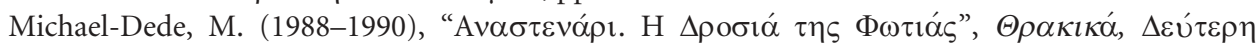

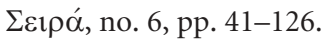

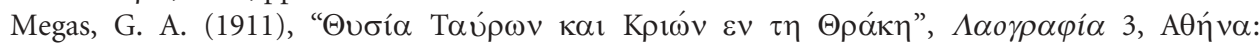
$\Sigma \alpha \kappa \varepsilon \lambda \lambda \alpha \rho i ́ o v$, pp. $148-171$.

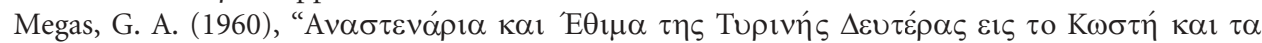

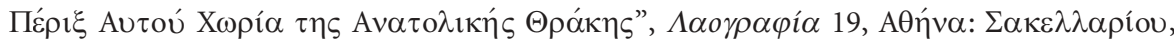
pp. $472-534$.

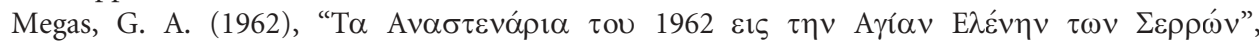

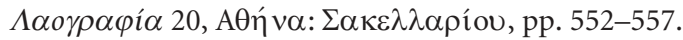

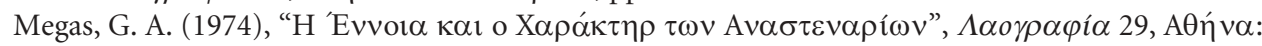
$\Sigma \alpha \kappa \varepsilon \lambda \lambda \alpha \rho i ́ o v$, pp. 3-18.

Orwell, G. (1949), Nineteen Eighty-Four. A Novel, Secker \& Warburg, London.

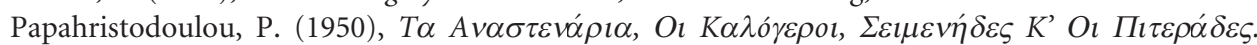

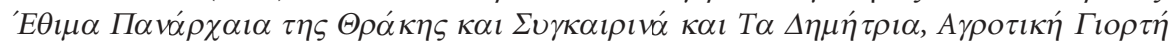

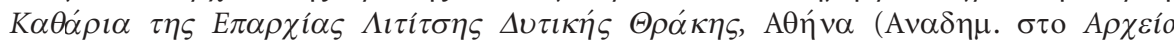

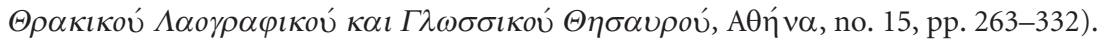

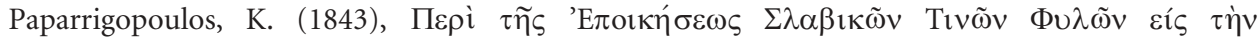

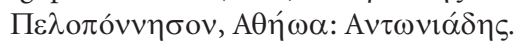

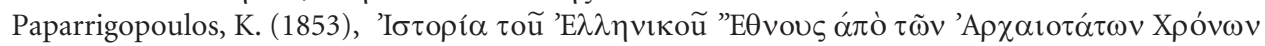

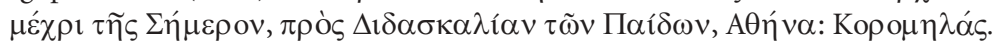




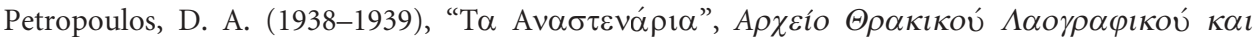

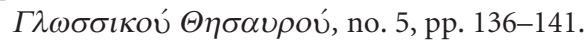

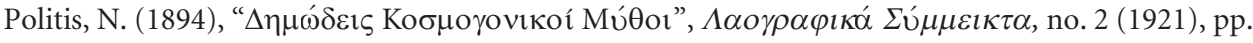
77-109.

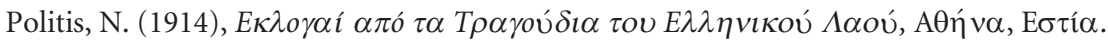

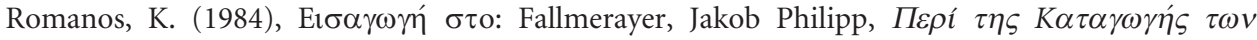

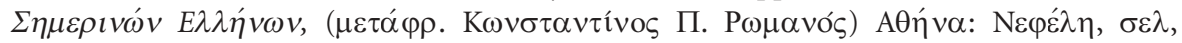
pp. 7-27.

Roudometof, V. (1998), "From Rum Millet to Greek nation: enlightenment, secularization, and national identity in Ottoman Balkan society, 1453-1821", Journal of Modern Greek Studies, no. 16, pp. 11-48.

Roudometof, V. (2001), Nationalism, Globalization, and Orthodoxy: The Social Origins of Ethnic Conflict in the Balkans, Westport, CT: Greenwood Press.

Tylor, E. B. (1871), Primitive Culture. Researches into the Development of Mythology, Philosophy, Religion, Art and Custom, Gordon Press, New York.

Veloudis, G. (1982), Jakob Philipp Fallmerayer and the Birth of Greek Historicism, Athens, Mnimon.

Xygalatas, D. (2007), Fire-Walking in Northern Greece: A Cognitive Approach to High-Arousal Rituals, Doctoral dissertation, Queen's University Belfast.

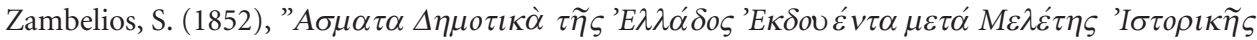

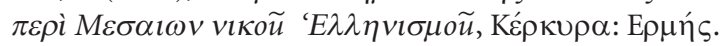

